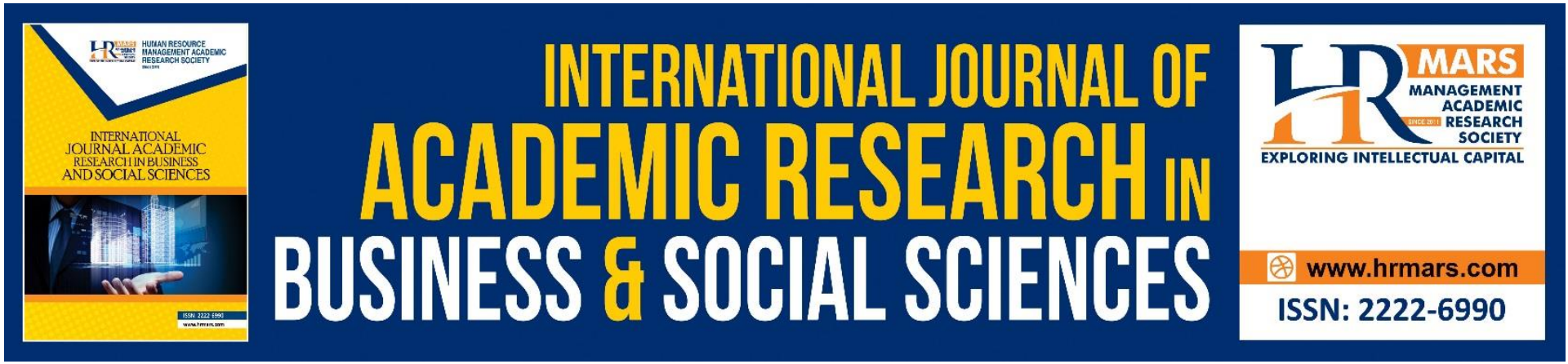

\title{
Issues and Trends of the Technical, Building and Engineering Drawing Subject in the Malaysian Vocational College.
}

Raihanah Salleh, Mohd Firdaus M. K, Rafeizah Z

To Link this Article: http://dx.doi.org/10.6007/IJARBSS/v11-i2/9203

DOI:10.6007/IJARBSS/v11-i2/9203

Received: 15 December 2020, Revised: 18 January 2021, Accepted: 31 January 2021

Published Online: 23 February 2021

In-Text Citation: (Salleh et al., 2021)

To Cite this Article: Salleh, R., Firdaus, M. M. K., \& Rafeizah, Z. (2021). Issues and Trends of the Technical, Building and Engineering Drawing Subject in the Malaysian Vocational College. International Journal of Academic Research in Business and Social Sciences, 11(2), 1274-1282.

Copyright: (C) 2021 The Author(s)

Published by Human Resource Management Academic Research Society (www.hrmars.com) This article is published under the Creative Commons Attribution (CC BY 4.0) license. Anyone may reproduce, distribute, translate and create derivative works of this article (for both commercial and non-commercial purposes), subject to full attribution to the original publication and authors. The full terms of this license may be seen at: http://creativecommons.org/licences/by/4.0/legalcode

Vol. 11, No. 2, 2021, Pg. 1274 - 1282

Full Terms \& Conditions of access and use can be found at http://hrmars.com/index.php/pages/detail/publication-ethics 


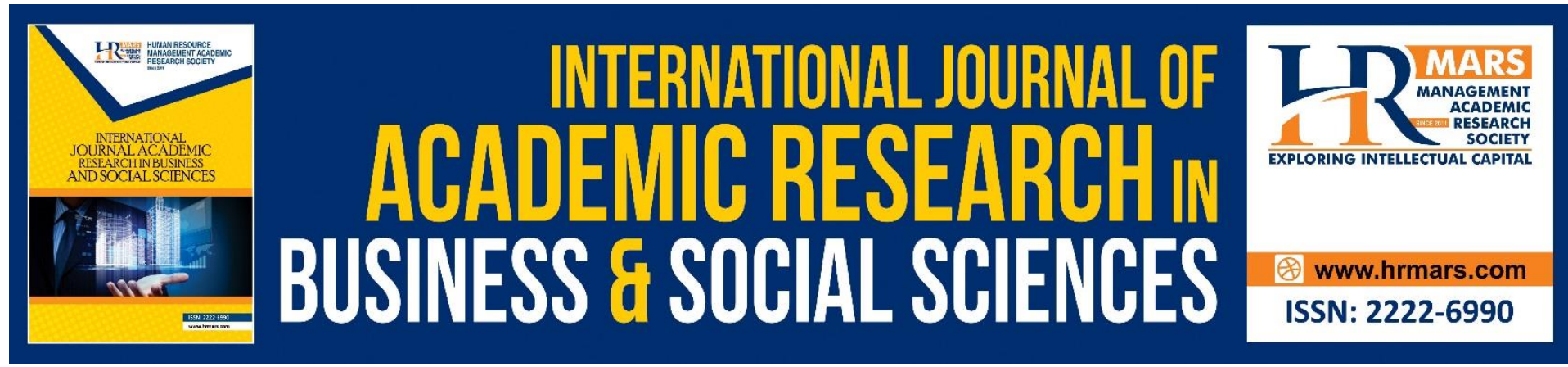

\title{
Issues and Trends of the Technical, Building and Engineering Drawing Subject in the Malaysian Vocational College.
}

\author{
Raihanah Salleh, Mohd Firdaus M. K, Rafeizah Z \\ Faculty of Technical and Vocational, Sultan Idris Education University, 35900 Tanjong Malim, \\ Perak, Malaysia
}

\begin{abstract}
The purpose of this study is to investigate the current practice in the vocational colleges that contributes to the issues found within the technical, building and engineering drawing subjects. The objective is to identify the effects of the current practice of these subjects' on the issues identified through the literature study. This study adopted exploratory design, and literature analysis and interview were conducted for data collection. Through the literature analysis, the common issues found within the subjects were highlighted. Then these issues were posted to selected teachers for further discussion. The teachers were selected based on their expertise and years of experience. Through the interview session, feedbacks from the teachers were obtained pertaining to their current practice which directly shed light on the issues being faced. Empirically, the findings suggested that there are several areas worth to be improved in order to promote better practice which could elevate the performance of the students.
\end{abstract}

Keywords: Technical, Building and Engineering Drawing, Malaysian Vocational Colleges

\section{Introduction}

Technical Drawing, Building Drawing and Engineering Drawing are different types of drawings. Nonetheless there are similarities found between them. Technical Drawing has 2-dimensional and 3-dimensional elements. It is a universal graphic language and used as a language of communication by the skilled and semi-skilled workers, technicians and also engineers to convey a clear picture of work in technical fields such as electrical / electronics, metal technology and wood technology (Oke \& Olakotan, 2019). Building Drawing offered at the vocational colleges is one of the components of building construction drawing, which consists of Orthographic Projection, Isometry and Building Drawing. It contains construction symbols, scales, drawing categories, working drawings, detailed drawings and electrical installation drawings (Usoro \& Bassey, 2019). Lastly, the Engineering Drawings have various fractions of titles, including Orthography and Isometry. It is associated with high visualization skills and learned by all students pursuing engineering (Ariffin1, Razali, Hamzah, Subramaniam, \& Rubani, 2017). From these definitions, although there is a clear distinction in its functions, 
they share similarities in terms of the objectives of the course, which is mainly on visualizations of objects through commonly shared topics within the courses.

\section{Methodology}

This study adopted an exploratory approach with literature analysis and interviews as the methods to collect data. The purpose of the literature analysis was to identify the issues associated with the technical, building and engineering drawings. The finding from this analysis were used to construct the interview questions to conduct the interviews. The interview was conducted to identify whether the current practice has any correlation to the issues identified earlier. The respondents for the interview were selected from the vocational colleges based on their expertise and years of experienced in teaching these subjects. All Interview sessions were conducted online due to the ongoing Covid-19 pandemic and the respondents' profile is shown in Table 1.

Table 1: Teachers' profile

\begin{tabular}{|c|c|c|}
\hline Teachers & Expertise & $\begin{array}{c}\text { Years of } \\
\text { Experience }\end{array}$ \\
\hline 1 & Geometry and Building Drawing & 22 \\
\hline 2 & Geometry and Building Drawing & 23 \\
\hline 3 & Geometry and Building Drawing & 20 \\
\hline 4 & Building Drawing and AutoCAD & 4 \\
\hline 5 & Technical Drawing & 5 \\
\hline 6 & Engineering Drawing & 3 \\
\hline
\end{tabular}

\section{Discussion on the Issues and Trends in Technical, Building and Engineering Drawing for Vocational Colleges}

There are similar issues related to Technical Drawing in the subjects of Building Drawing and Engineering Drawing. These three subjects are associated with each other because they have several similarities in the content, namely Orthographic Projection and Isometric View (Ariffin1 et al., 2017). Technical Drawing contains descriptions of 2-dimensional objects and 3 dimensions. This subject needs to be mastered by students by the end of the course. It requires students to view, illustrate and construct Orthographic Projection from the perspective of Isometric drawing (Ariffin1 et al., 2017; Sanchit Ingale, Anirudh Srinivasan, 2018). From another perspective, although Technical Drawing and Engineering Drawing have different names, (Kayhan, 2005) made a connection between these two, where they include visual skills, graphic communication, and have standard conventions and rules of drawing.

Building Drawing is offered to all students in the vocational college, in Construction Technology Program. It is a compulsory subject for semester 1 students pursuing Malaysian Vocational Diploma (DVM). It includes 14 lecture weeks in one semester, and 5 lecture hours per week. This subject is important for students to master, so they will be able to read the construction drawing once they enter the working world. It is the duty and responsibility of the teachers to find the best method in delivering the content to the students. Based on the literature review, there are a number of issues discussed in relation to the Technical Drawing. The issues are classified and presented based on the country of research in Table 2 . 
INTERNATIONAL JOURNAL OF ACADEMIC RESEARCH IN BUSINESS AND SOCIAL SCIENCES Vol. 11, No. 2, 2021, E-ISSN: 2222-6990 @ 2021 HRMARS

Table 2: Issues related to Technical, Building ang Engineering Drawings

\begin{tabular}{|l|l|c|}
\hline \multicolumn{1}{|c|}{ Author } & \multicolumn{1}{|c|}{ Issues } & Country \\
\hline Sorby (2009) & Spatial visualization ability & USA \\
\hline Farzeha (2018) & Visual skills of underperforming students & Malaysia \\
\hline Ariffin et al. (2017) & Level of visualizing skills & Malaysia \\
\hline Tahfizam (2017) & Lack of infrastructures facilities & Malaysia \\
\hline Tahfizam (2018) & Lack of staff-training & Malaysia \\
\hline Nurfajar (2018) & Has not achieved industrial standard & Indonesia \\
\hline Bairaktrova (2017) & Weakness of hand-mind coordination & Virginia \\
\hline Ibanez et al. (2017) & Lighting in the classroom & Brazil \\
\hline
\end{tabular}

\section{a) Visual-spatial.}

Spatial visual refers to an individual's ability to imagine an object, modified by changing the position or opening the object's orientation. Sorby (2009) in his study related to engineering drawings identified that there were problems and differences in students' abilities based on their genders, to use the mind to rotate 3-D objects or spatial skills. He later on added that the problem arisen due to the series of modifications to the engineering education curriculum in the 1950s. It was modified and deviated from the original purpose for engineering field. The educational curriculum which focused on the form of visual, sensory and artistic, was converted to analytical methods. Consequently, the tactical and visual methods in the engineering curriculum were removed. As a result, perception and reasoning became visual thinking skills and it neglected the emphasis on visualization and visual thinking skills, which were the original elements in the engineering education curriculum.

In contrast to that, the findings obtained by Farzeeha (2017) revealed that the engineering students in Malaysia have moderately high level of visual ability. She studied to find the best methods to improve the spatial ability of students. It was highlighted that the lack of spatial visual skills among engineering students in semester one was a direct consequence of different backgrounds and past school experiences. Besides, it was also due to the insufficient coursework instructions and graphic introduction notes given to the students. This affected the teacher's ability to deliver the subject more efficiently, thus leaving an impact on the students, trying understanding the content taught by them. In addition, (Ariffin et al. 2017) supported this and highlighted that it will also affect the creativity of students to create something new. It also influences and hinders the efforts to produce technical and vocational graduates who can meet the industrial demands.

\section{b). Colleges Facilities}

Infrastructure facilities is the main necessity in any school. It is crucial in every school in order to develop a conducive learning environment for everyone. The failure of the school administration to provide complete infrastructure caused various problems. (Mohd Taib \& Mustapha, 2017) found that the main problem in his study on schools offering technical subjects were the incomplete workshop equipment, lack of ICT facilities, maintenance of equipment, limited learning software, and lack of teaching aids. This happened since little to 
no provision was taken to repair the facilities. He listed the results of observational analysis on infrastructure facilities as shown in Table 3 below.

Table 3: Analysis on infrastructure facilities (adoption of Mohd Tafizam Mohd Taib \& Ramlee Mustapha, 2017)

\begin{tabular}{|c|c|c|c|c|}
\hline \multirow{2}{*}{ Infrastructure } & \multicolumn{2}{|c|}{ Available } & \multicolumn{2}{c|}{ None } \\
\cline { 2 - 5 } & Number & Percent & Number & Percent \\
\hline Workshop & 12 & 66.7 & 6 & 33.3 \\
\hline Hand tools & 9 & 50.0 & 9 & 50.0 \\
\hline Machine tools & 7 & 38.9 & 11 & 61.1 \\
\hline Tools' store & 12 & 66.7 & 6 & 33.3 \\
\hline Courseware CD & 10 & 55.6 & 8 & 44.4 \\
\hline
\end{tabular}

Based on Table 3, it can be concluded that the critically needed infrastructure was machines because only $38.9 \%$ were available, which was less than half of the equipment needs. The second most critical one was the hand tools which were used by the teachers and students during the teaching and learning process.

This issue distorted the efficiency of teaching and learning process in the schools involved. At the same time, it reduced the motivation of teachers to impart knowledge and students to seek knowledge.

\section{c). Staff Competencies and Trainings.}

Based on the study by Mohd Taib (2018), it was found that there were no training courses conducted for teachers to expose them to the use of tools, the use of Autocad and skills in line with the subjects taught in high school. This situation, if continued, may cause the teachers to lose confidence in their abilities to use certain equipment and machines, especially for those who were not trained. This requirement is important in technical fields such as Engineering Technology, Design and Engineering Drawing.

As a result, this will cause the students who are supposed to receive knowledge and skills to fail because they cannot be assisted by their teachers and the school. Ultimately, knowledge and skills become more and more difficult to be delivered by the teachers as they cannot integrate the theoretical knowledge into practice, thus defeating the essence of the curriculum and vocational education.

\section{d). Industry Standard Compliance.}

A study in Indonesia by Nurfajar, Wahyuningaji, \& Dardiri, (2019) revealed that vocational programs are expected to produce graduates who can interpret, analyze, and evaluate building drawings. However, in reality, students were yet to be fully competent. In fact, some companies questioned the knowledge and skills of students in drawing.

The core to this was due to the weakness of visualization and knowledge in understanding drawing techniques among these students. In a long run, it affects the teachers and vocational students, thus damaging the image of educational institutions and causing the industry to close opportunities for students from vocational fields.

\section{e). Weaknesses of hand-mind coordination.}

Students' skills in forming technical drawings and techniques can be an advantage in their learning progression because not all students can attain it without teachers' guidance. 
(Bairaktarova, 2017) mentioned that in the early 1800s, the worldwide engineering curriculum of Asia, Central and Eastern Europe contained two subjects, namely Geometry Description (Descriptive Geometry) and Manual Drawing. They were inculcated to improve the hand-mind coordination to produce drawings. However, due to the development of computer (CAD), manual training were slowly discontinued from being practiced (Alada, 2018).

The changes that took place caused the technical and engineering students to have difficulties in coordinating their hand and mind to draw. Žeželj \& Miler (2018) stated that the engineering students need to master the basics of drawing, before being able to use CAD properly because the basics of drawing are composed of the skill of rotating, changing the position of objects in the mind before transferring it onto the drawing.

This issue to some extent contributes to the weakness of students' visualization skills in describing objects in real terms. Students' difficulty to draw an object will make the drawing difficult to be interpret by the teacher and those involved in technical drawing.

\section{f). Classroom Condition.}

The effect of lighting in the classroom should not be underestimated which can highly affect the students' performance in technical drawing. A study by Alada (2018) described that classrooms which are less comfortable in terms of lighting can affect learning. Supporting this, Žeželj \& Miler (2018) proposed that the comfort of lighting in a drawing classroom or studio are crucial to students doing drawing work. Lack of lighting in the drawing classroom affect the quality of drawings produced, especially drawings that need to be provided manually, in which the cleanliness and neatness of the drawings matter a lot. Without proper lighting in a drawing studio, the quality of the drawings and the accuracy of the working drawings produced will be lowered, thus affecting the overall quality of the work.

\section{Trends of Technical Drawing}

In Malaysia, technical drawings are studied by students enrolled in Technical Schools, Vocational Colleges, Matriculation Colleges and Polytechnics. In addition, selected number of secondary schools also offer this subject. Various categories of schools and educational institutions offer this subject, thus possibly there are different approaches in teaching and learning methods for this subject (Darby \& Rashid, 2017). Most of the teachers choose the memorization and training approach to fit in the current examination-oriented education system. This prevents students from thinking outside of the box, and has created a negative and selfish attitude. However, teachers usually emphasize on drilling and exercises in mastering drawing techniques.

Experience in producing technical and engineering drawings contributes to spatial visualization, although almost all drawing techniques are taught through the use of CAD. In fact, the skills of using the mind and hands are very necessary for all technical and engineering students. Because the teaching of manual drawing techniques is still appropriate to this day. This is acknowledged by (Akasah \& Alias, 2010; Bairaktarova, 2017) which suggest that it is beneficial to students who master mind and hand skills. They can improve their skills and knowledge in the use of drawing equipment and more easily use Computer Aided Design (CAD) software. The combination is important, to strengthen students' spatial visualization skills in technical drawing as well as engineering drawing. 


\section{a). Practice of Technical Drawing and Building Drawing teachers}

The drawing techniques and practices among teachers are as important as the existence of students in every school. There are several studies that discussed the weaknesses of students in mastering this subject. However, this writing is more about the teachers in Malaysia. (Darby \& Rashid ,2017) stated that most of the teachers choose conventional teaching methods and aids in teaching drawings. This method is seen as less effective in building students' knowledge and understanding, especially in technical drawing.

Most of the teachers in vocational colleges are graduates from Technical Teachers College. Thus, they are well versed with Technical Drawing which is a compulsory subject in teaching colleges. The subject has a specific set of skills and knowledge to be mastered, including spatial visualization skills that only a number of well-trained teachers can execute and teach to their students. For that very reason, they are prioritized to teach Technical Drawing, which is rather known as Building Drawing in vocational colleges, and it has become a norm among them.

In vocational colleges in particular, Building Drawing is studied by semester 1 students pursuing the Malaysian Vocational Diploma. This subject will usually be taught by experienced teacher in the field of technical drawing or building. However, the opposite will happen when a vocational college lacks teacher in this particular field.

Based on observations and telephone conversations conducted with the vocational college teachers in the states of Selangor, Perak, Perlis, Kedah, Pahang and Johor, it was found that the teachers who teach this subject are experts in this and possess the required skills to do so. Detailed analysis of the results answered the questions about their practices in vocational colleges for the subject of Building Drawing, and are presented below.

\section{b). The Practice of Building Drawing Teachers in Vocational Colleges}

Based on the findings of telephone conversations, a several deductions were made and classified as below:

1. Teachers' competence - Learning and teaching experience in drawing are crucial to be known before deciding if a teacher should teach the Building Drawing subject. This is evident in the Vocational Colleges. Based on the results of the conversation, it was found that the teachers with 10 years of experience and above have less problems in teaching Building Drawing. However, the also agreed that they still need to acquire the latest knowledge and view that a teacher should be competent before teaching the students. On the other hand, teachers with less than 5 years experiences and below admitted that they are facing time constraints to find and prepare teaching materials. It takes quite a while to find and process the reference material before starting the lesson.

2. Teachers Training - Courses and training should be provided to new teachers who teach Building Drawing to further enhance their knowledge. However, the results of the conversation found that during the last 5 years, both new teachers and experienced teachers did not attend any courses or training related to the subject of Building Painting. On the contrary, two teachers informed about the available courses, but limited 
to AUTOCAD only. Everyone agreed that if they were given the opportunity, they would like to attend any training or courses related to Building Drawing to improve their knowledge and skills in this subject.

3. Curriculum and Syllabus - Curriculum and content of the syllabus need to be improved and modified to meet the actual needs of Building Drawing. This will help the teachers to provide real knowledge and skills for the subject of Building Drawing. In addition, it is also needed to meet the real needs of the industry. Based on the conversation, 3 teachers admitted to facing problems in adhering to the content of the lesson, based on the existing curriculum and syllabus. 2 of the teachers had to develop their own teaching materials due to insufficient materials and at the same time, they are less confident; if materials obtained are on par with the curriculum and syllabus. The rest of them look for other alternatives to develop teaching materials according to their own understanding. This matter needs to be given attention by the relevant parties, so the teachers will have cohesive idea in preparing teaching materials for their students

4. Infrastructure and equipment - In-class infrastructure and teaching aids need to be improved, including references. Based on the observation and interview, all teachers agreed that the existing classroom were less conducive to be used as drawing studio. The condition in the classroom including the facilities, lighting and airflow were not designed to ensure a comfortable learning environment for the students. It is suggested that to ensure the learning process to be effective, the condition of the class should to upgraded and improved.

5. Benchmark / Level of teaching - There is a need to set a benchmark or level for teachers to complete teaching in the classroom. Teachers should be given guidelines to deliver their lessons in Building Drawing. The fact is that in the vocational college, the teachers do not know the extent to which lessons need to be completed. Based on the conversation, the six teachers conducted the lessons based only on their own understanding, although the curriculum and syllabus are present. For a more concrete reference, they still need a benchmark to know the extent of knowledge of Building Drawing to be taught to their students. This issue needs to be addressed so that the teachers will not be wasting their time on teaching the less important topics to their students.

\section{Conclusion}

Based on the findings of this study, it can be deduced that the current practice in the vocational colleges had correlation to some of the issues identified in the literature. It is suggested that the practice should be improved, and the new issues based on the current practices and situations should be addressed. Firstly, a teacher's knowledge and experience of teaching in Building drawing should be considered before assigning him or her to teach the subject. Secondly, teacher training is an important aspect to take note of. Courses and trainings must be given to new teachers who teach Building Drawing to increase their knowledge and readiness to teach. Thirdly, the Building Drawing's curriculum and syllabus need to be improved and modified to meet the actual needs of Building Drawing in current world. This will facilitate the teachers to impart real knowledge and skills to their students, especially spatial visual skills which is a crucial topic in other countries and Malaysia. Lastly, the infrastructure and equipment which are the cores of a successful 
technical subject need to be improved, including the reference materials. This will benefit the teachers to conduct more successful lessons, provide conducive environment and can improve the performance of students learning this subject.

In moving towards the Industrial Revolution (IR 4.0) which demands for more vocational and technical supports, efforts are needed from all parties to improve the Building Drawing subject, and aid the teachers to face the issues, constraints, and challenges in vocational colleges. As practitioners, the teachers cannot feel comfortable with their traditional teaching methods as before. They need to improvise their pedagogy, learning activities, teaching methods, and teaching aids in order to move forward to meet the challenges of globalization and demands of their core tasks. Therefore, efforts from both sides are the only ways to minimize the identified problems and constraints in the Building Drawing subject.

\section{References}

Alada, H. (2018). Challenges Of "Teaching And Learning" In Technical Drawing Course : A Comparison Of Architectural And. Journal Of Teaching And Education, 08(02), 1-12.

Ariffin, A., Razali, N. M., Hamzah, N., Subramaniam, T. S., \& Rubani, S. N. K. (2017). Tahap Kemahiran Visualisasi Bagi Mata Pelajaran Lukisan Kejuruteraan Di UTHM. 1-8.

Bairaktarova, D. (2017). Coordinating Mind And Hand: The Importance Of Manual Drawing And Descriptive Geometry Instruction In A Cad-Oriented Engineering Design Graphics Class. Engineering Design Graphics Journal, 81(3), 1-16.

Darby, N. M., \& Rashid, A. M. (2017). Critical Thinking Disposition : The Effects of Infusion Approach in Engineering Drawing. Journal of Education and Learning, 6(3), 305-311. https://doi.org/10.5539/jel.v6n3p305

Farzeeha, A. (2017). Spatial Visualization Ability Among Engineering Students In Malaysia.

Taib, M. R. M. (2018). Sains Humanika Evaluation of the Implementation of Engineering Technology, Engineering Drawing and Invention Subjects in Malaysian Secondary Schools. 3, 63-71.

Taib, M. T., \& Mustapha, R. (2017). Kemudahan Prasarana Dalam Pelaksanaan Mata Pelajaran Teknologi Kejuruteraan, Lukisan Kejuruteraan Dan Reka Cipta Di Sekolah Menengah Harian Malaysia. Sains Humanika, 9(1-5), 11-17. https://doi.org/10.11113/sh.v9n1-5.1171

Nurfajar, A. A., Wahyuningaji, R. P., \& Dardiri, A. (2019). Impact of Vocational Curriculum 2013 on the Role of Vocational School Graduates in Industrial Construction Services. 242(130), 133-135. https://doi.org/10.2991/icovet-18.2019.33

Oke, J. O., \& Olakotan, O. O. (2019). Enhancing Effectiveness in Teaching and Learning Technical Drawing for Sustainable Development in Nigerian Technical Colleges. 1, 1218.

Sorby, S. A. (2009). Educational Research in Developing 3-D Spatial Skills for Engineering Students. (786945360). https://doi.org/10.1080/09500690802595839

Usoro, A. D., \& Bassey, O. E. (2019). Edutainment Teaching Technique and Students' Skills Performance in Building Drawing in Technical Colleges in Akwa Ibom State. Archives of Current Research International, 16(4), 1-10. https://doi.org/10.9734/acri/2019/v16i430096

Žeželj, D., \& Miler, D. (2018). Manufacturing technology-based approach to teaching engineering drawing. Proceedings of International Design Conference, DESIGN, 5. https://doi.org/10.21278/idc.2018.0530 